Ege Tıp Dergisi / Ege Journal of Medicine 2018;57(1):57-59

\title{
Herediter multiple ekzostoz
}

\section{Hereditary multiple exostoses}

\author{
Illknur Aykurt Karlıbel ${ }^{1} \quad$ Asiye Mukaddes Erol ${ }^{1} \quad$ Lale Altan İnceoğlu² $^{2}$ Mustafa Özer $^{3}$
}

${ }^{1}$ Yüksek İhtisas Eğitim ve Araştırma Hastanesi, Fiziksel Tıp ve Rehabilitasyon Kliniği, Bursa, Türkiye

${ }^{2}$ Uludağ Üniversitesi Tıp Fakültesi, Fiziksel Tıp ve Rehabilitasyon Anabilim Dalı, Bursa, Türkiye

${ }^{3}$ Gebze Devlet Hastanesi, Fiziksel Tıp ve Rehabilitasyon Kliniği, Kocaeli, Türkiye

\section{Öz}

Herediter multiple ekzostoz, çoğunlukla uzun kemiklerin juksta-epifizer bölgesinden köken alan ekzositozlarla karakterize otozomal dominant bir hastalıktır. Hastalar en sık eklem yakınında tek veya çok sayıda sert, ağrısız kitlelerle prezente olur. En yaygın komplikasyonları ağrı, eklem hareket kısıtıığı, ekstremite eşitsizlikleri, büyüme geriliği, damar-sinir basısı ve malign dejenerasyondur. Bu yazıda, herediter multiple ekzostoz tanılı bir olguyu sunmayı ve ilgili literatür eşliğinde klinik özelliklerini ve tedavide rehabilitasyonun etkinliğini tartışmayı amaçladık.

Anahtar Sözcükler: Herediter multiple ekzostoz, eklem hareket kısıtıı̆ı̆ı, ekzostoz

\begin{abstract}
Hereditary multiple exostoses is an autosomal dominant disease which is characterized by exostoses that originate most commonly from the juxta-epiphysial region of the long bones. Patients usually present with single or multiple, firm, painless masses near the joints. The most common complications are pain, restricted joint motion, extremity asymmetry, growth retardation, neurovascular compression and malignant degeneration. In this paper, we aimed to present a case with diagnosis of hereditary multiple exostoses and discuss the clinical features and efficacy of rehabilitation with relevant literature.
\end{abstract}

Keywords: Hereditary multiple exostoses, restricted joint motion, exostosis

\section{Giriş}

Herediter multiple ekzostoz (HME) çok sayıda ekzostozların varlığı ile karakterize, farklı fenotipik bulgularla ortaya çıkabilen otozomal dominant geçişli bir hastalıktır (1). Ekzostoz kemik yüzeyinden dışarı doğru uzanan benign kemik tümörüdür. Kıkırdak ile kaplı ekzostozlara osteokondrom denir. Osteokondromlar (osteokartilajenöz ekzostoz) tekli olabileceği gibi HME'deki gibi çoklu görülebilir. Osteokondromların en sık yerleşim yerleri distal femur, proksimal tibia ve humerustur (2). HME, osteokondromlara bağlı hem fonksiyonel hem de kozmetik problemlere neden olabilir. Osteokondromlar büyüme plağına zarar vererek ekstremite kısalığı, uzun kemiklerde eğilme, psödomadelung deformitesi, eklem hareket kısıtlılı̆ı ve boy kısalığı gibi çeşitli iskelet deformitelerinin gelişmesine yol açabilir (3).

\footnotetext{
Yazışma Adresi: Asiye Mukaddes Erol

Yüksek İhtisas Eğitim ve Araştırma Hastanesi, Fiziksel Tıp ve Rehabilitasyon Kliniği, Bursa, Türkiye

Makalenin Geliş Tarihi: 01.11.2016 Kabul Tarihi: 03.05.2017
}

Bu çalışmada yaygın ağrı, eklem hareket kısıtlılığı ve uyuşma şikayetleri ile başvuran HME tanılı bir olguyu tedavide rehabilitasyonun etkinliğini de ele alarak literatür eşliğinde tartışmayı amaçladık.

\section{Olgu Sunumu}

Yirmi altı yaşında erkek hasta yaygın eklem ağrısı, omuz ve kalçadan başlayarak distale yayılan uyuşma, omuz, kalça ve dizlerde hareket kısıtlıı̆̆ı şikayetleri ile kliniğimize başvurdu. Hikayesinden, altı yaşında iken omuz ve diz eklemlerinde hareket kısıtlılığı gelişmeye başlayan hastaya başvurduğu hastanede herediter multiple ekzostoz tanısı konulduğu, 14 yaşında sol omuzdan ve 16 yaşında da her iki dizden opere edildiği öğrenildi. Soy geçmiş sorgulandığında annesinde de benzer şikayetler olduğu öğrenildi. Hastanın genel durumu iyi, sistemik muayenesi doğaldı. Kas iskelet sistemi muayenesinde aktif eklem hareket açıklıkları (EHA) incelendi. Her iki omuz internal rotasyonu $45^{\circ}$, her iki dirsek ekstansiyonu son $10^{\circ}$, her iki kalça fleksiyonu $65^{\circ}$, her iki kalça ekstansiyonu son $10^{\circ}$ ve her iki diz fleksiyonu ise $100^{\circ}$ derecede kısıtlı ve ağrılıydı. Diğer eklem hareket açıklıkları ise normal sınırlardaydı. Her iki 
kalçada Thomas testi pozitifti. Sağ dizde 20 derece sol dizde 15 derece valgus açılanması mevcuttu. Her iki üst ve alt ekstremitede kas gücü tam, derin tendon refleksleri normoaktif, patolojik refleksler negatifti. Rutin laboratuvar tetkikleri normal sınırlardaydı. Radyolojik incelemesinde her iki femur proksimali ve distali, her iki humerus proksimal ve distali, her iki tibia proksimal ve distali ve her iki fibulada ekzostozlar tespit edildi (Şekil-1).

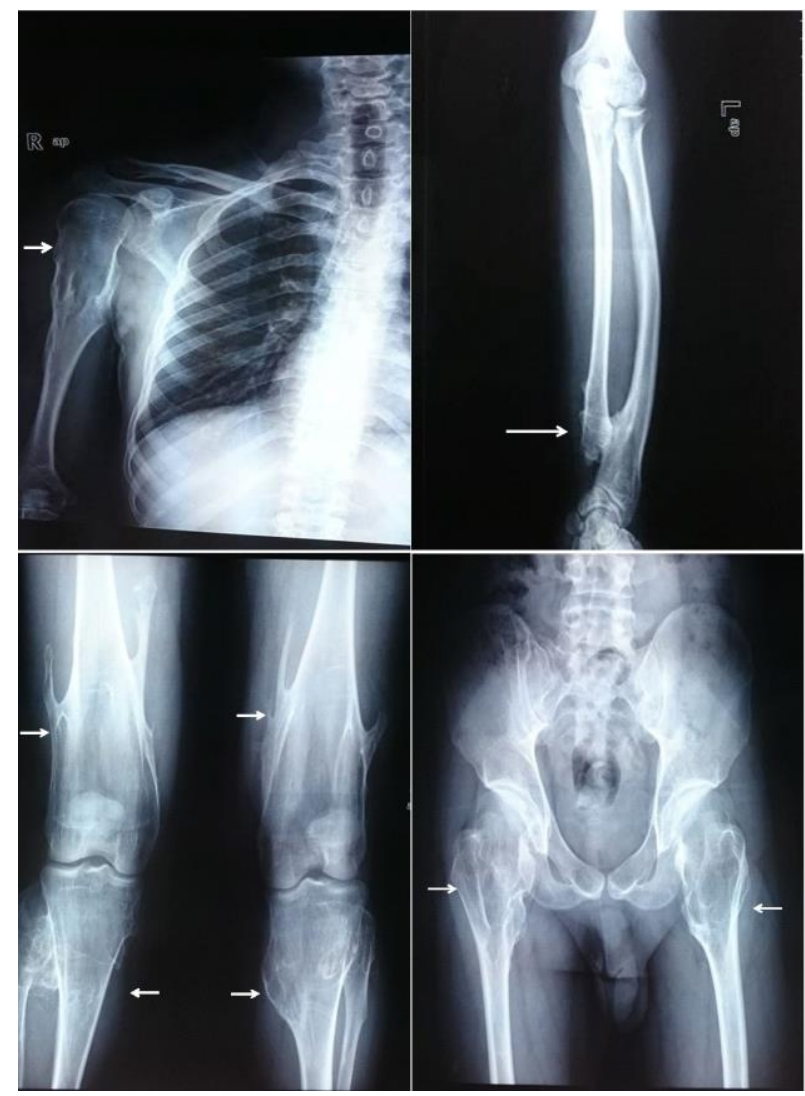

Şekil-1. X-Ray incelemede her iki femur, humerus ve tibia proksimali ve distalinde sesil ekzositozlar.

Her iki üst ve alt ekstremite tuzak nöropatisi açısından istenen EMG sonucu normal olarak geldi. Hasta, eklem hareket açıkığını (EHA) arttırmak ve ağrıyı azaltmak amacıyla fizik tedavi ve rehabilitasyon programına alındı. Ağrılı eklemlere 20 seans hotpack, ultrason ve transcutaneous electrical nerve stimulation (TENS) tedavileri uygulandı. Germe, EHA ve güçlendirme egzersizleri ile yürüme eğitimi verildi. Fizik tedavi ve rehabilitasyon programı sonrasında eklem hareket açıklıkları incelendiğinde her iki omuz internal rotasyonu $30^{\circ}$, her iki dirsek ekstansiyonu son $5^{\circ}$ ve her iki kalça ekstansiyonu son $5^{\circ}$ derecede kısıtlıydı. Her iki kalça fleksiyonu $95^{\circ}$ ve her iki diz fleksiyonu ise $115^{\circ}$ dereceydi. Yatışta visuel analog skala (VAS) skoru 9 (010) olan hastanın tedaviden sonra VAS skoru 3'e geriledi. Yürüme hızında ve adım uzunluğunda artma, günlük yaşam aktivitelerinde iyileşme sağlandı. Hastanın ağrısında belirgin azalma ve fonksiyonel durumunda iyileşme sağlanması üzerine hastanın da isteği doğrultusunda hastada cerrahi müdahale düşünülmedi. EHA'da artma ve hastanın operasyon istememesi üzerine hasta cerrahi açıdan değerlendirilmedi. Hastanın takiplerinde klinik ve radyolojik olarak malign dejenerasyonu düşündürecek bulgulara rastlanmadı.

Hastadan tıbbi verilerinin yayınlanabileceğine ilişkin yazılı onam belgesi alındı.

\section{Tartışma}

HME farklı fenotipik bulgularla karşımıza çıkabilen kemik tümörüdür. Hastalık genellikle otozomal dominant geçiş gösterse de spontan mutasyonlar da görülebilmektedir (4). Prevalansı 1/50.000'dir. Kadınlarda inkomplet penetransa eğilim olduğundan dolayı klinik tablo daha hafif seyirlidir(3). HME patogenezinde, 8. ve 11. kromozomlarında bulunan EXT tümör supresör genlerindeki mutasyonlar rol oynamaktadır $(2,4,5)$. EXT1 geni $8 q 23-24$ ve EXT2 geni 11p11-p12 kromozomal bölgesinde bulunur. Hem EXT1 hem de EXT2 heparan sülfat ve proteoglikan sentezinde görevli glikoziltransferazları kodlamaktadır. Heparan sülfatın yapısında bulunan polisakkarit dizilerinin büyüme faktörleri ile ilişkili sinyal iletiminde, hücre çoğalmasında ve adhezyonunda rol oynadığı düşünülmektedir. Bu genlerdeki mutasyonlar kıkırdak farklılaşmasında bozulmaya ve ekzostoz gelişimine yol açmaktadır $(2,4,6)$. EXT1 mutasyonu ciddi ve yaygın hastalık seyriyle ilişkilidir (3).

HME tanısı esas olarak hastanın kliniğine ve radyolojik incelemeye göre konulabilir. Radyografide uzun kemiklerin juksta-epifizer bölgesinden köken alan en az iki osteokondroma rastlandığında HME tanısı konulabilir. Genellikle hastalarda aile hikayesi de mevcuttur (2). Osteokondromlar, doğumda genellikle belirti vermez. Çocukluk ve ergenlik dönemi boyunca, büyüme plağının kapanmasına kadar büyür. Komplike olmayan lezyonlar genellikle büyüme plağının kapanmasından sonra büyüme göstermez $(1,4)$. HME'de ekstremite kısalığı, uzun kemiklerde eğilme, psödo-madelung deformitesi, eklem hareket kısıtııı̆ı ve boy kısalığı gibi çeşitli iskelet deformiteleri görülür (1). Olgumuzda da sol ulnada kısalma, omuz, dirsek ve diz eklemlerinde hareket kısıtılığı ve dizlerde valgus deformitesi mevcuttu. HME, kozmetik ve iskelet deformiteleri dışında damar-sinir basısı ve malign dejenerasyon gibi ciddi komplikasyonlara da yol açabilir. Hastada damar basısı yoktu fakat peroneal sinir basısı nedeniyle operasyon öyküsü mevcuttu. Yapılan EMG'de periferik sinir tuzaklanmayı düşündürecek bulgu saptanmadı.

Malign dejenerasyon \%0.5-5 olguda görülmektedir. En sık kondrosarkom görülse de oldukça nadir karşılaşılan bir durumdur $(1,3)$. Malign dejenerasyon açısından hastaların mutlaka klinik ve radyolojik olarak takip edilmesi gerekir. Klinikte ağrının artması, şişliklerde büyüme, radyolojik görüntülemede düzensiz kontur, 
kemik destrüksiyonu ve dağınık kalsifikasyonlar malign dejenerasyon intimalini düşündürmelidir (7). Hastanın klinik takip ve radyolojik incelemelerinde malign dejenerasyonu düşündürecek bulguya rastlanmadı.

HME tedavi yönetimi zorlayıcı olabilir. Çocukluk döneminde büyüme süreci göz önünde bulundurulmalıdır. Büyüme bozukluğu, nörovasküler yapılara bası, şiddetli ağrı, eklem hareketlerinde ileri derecede kısıtlılık varsa cerrahi tedavi uygulanır (1-3). Bu durumların dışında kabul edilen yaklaşım konservatif tedavidir. Darilek ve ark. (8) 293 HME'li hastada yaptığı çalışmada hastaların \%84'ünde ağrı şikayeti mevcuttu. Ağrılı olanların \%55.1'i de yaygın ağrı tariflemekteydi. Goud ve ark. (9) yaptığı çalışmada ise HME'li hastalarda ağrının günlük yaşam aktivitelerinin yanı sıra sosyal yaşam ve psikolojik durum üzerine de yaygın etkileri olan önemli bir problem olduğu gösterilmiştir. Bu nedenle ağrı HME'li bireylerin tedavisinde ele alınması gereken önemli bir sorundur. Bizim olgumuzda her iki omuz, dirsek, kalça ve dizde eklem hareket açıklığı kısıtılığı ve bilateral genu valgumu vardı. Hastanın sol omuz ve sağ dizden eklem hareket kısıtlıığı ve peroneal sinir basısına bağlı operasyon hikayesi mevcuttu. Ağrı, eklem hareket kısıtılığı ve şekil bozuklukları hastanın günlük aktivitelerinde zorlanmasına ve yürüyüşünde bozukluğa yol açmaktaydı. Fizik tedavi ve rehabilitasyon programı sonrası hastanın ağrısında azalma, EHA'da artma ve yürüyüşünde iyileşme sağlandı. Hastanın sosyal ve sportif faaliyetlere katılımı arttı.

Sonuç olarak hem kozmetik hem de fonksiyonel problemlere yol açabilen, farklı fenotipik bulgularla ortaya çıkabilen HME tedavi sürecinde fizik tedavi ve rehabilitasyon, hastalarda ağrının azalmasına, hareket açıklığında artmaya ve günlük yaşam aktivitelerinde iyileşmeye yardımcı olabilir.

\section{Kaynaklar}

1. Ryckx A, Somers Jan FA, Allaert A. Hereditary Multiple Exostosis. Acta Orthop Belg 2013;79(6):597-607.

2. Stieber JR, Dormans JP. Manifestations of Hereditary Multiple Exostoses. J Am Acad Orthop Surg 2005;13(2):110-20.

3. Bovée JV. Multipl osteochondromas. Orphanet J Rare Dis 2008;13(3)3.

4. Jamsheer A, Socha M, Sowińska-Seidler A, Telega K, Trzeciak T, Latos-Bieleńska A. Mutational screening of EXT1 and EXT2 genes in Polish patients with hereditary multiple exostoses. J Appl Genetics 2014;55(2):183-8.

5. Wuyts W, Van Hul W, De Boulle K, et al. Mutations in the EXT1 and EXT2 genes in hereditary multiple exostoses. Am J Hum Genet 1998;62(2):346-54.

6. Legeai-Mallet L, Margaritte-Jeannin P, Lemdani M, Le Merrer M, Munnich A. An extension of the admixture test for the study of genetic heterogeneity in hereditary multiple exostoses. Hum Genet 1997;99(3):298-302.

7. Temizöz O, Bayram I, Akpınar F, Etlik Ö, Güler M, Sakarya ME. Malign transformasyon gösteren osteokondromatozis olgusunda radyolojik bulgular. Tıp Araştırmaları Dergisi 2003:1(3):31-4.

8. Darilek S, Wicklund C, Novy D, et al. Hereditary multiple exostosis and pain. J Pediatr Orthop 2005;25(3):369-76.

9. Goud AL, de Lange J, Scholtes VA, Bulstra SK, Ham SJ. Pain, physical and social functioning, and quality of life in individuals with multiple hereditary exostoses in The Netherlands: A national cohort study. J Bone Joint Surg Am 2012;94(11):1013-20. 